\title{
SUKUK: INSTRUMEN INVESTASI YANG HALAL DAN MENJANJIKAN
}

\author{
Nur Kholis ${ }^{1}$
}

\begin{abstract}
This article is aimed to analyse the development of Sukuk (Islamic bond) in Indonesia. From historical perspective, sukuk had been implemented in medieval Islam as financial tranfer tools in commerce and other activities. In modern context, sukuk has worldy known as sharia financial instrument that give its holders right of ownership of specific asset, advantage value, and ownership of asset in investment of project. Sukuk are now created also by a government, which is available for personal investors (retail sukuk) as government sharia bond in both Rupiah or foreign currencies. Sukuk has been a promising sharia-based investment instrument mainly because of government assurance and low risk. It is therefore a chance for Moslems in Indonesia to invest their assets in this financial instrument for its compliance with sharia and benefecial function for country development.
\end{abstract}

Keywords: sukuk ritel, obligasi negara, investasi syariah.

\section{Pendahuluan}

Salah satu instrumen keuangan Islam yang tengah berkembang pesat saat ini adalah sukuk. Sukuk pada hakikatnya merupakan sertifikat kepemilikan atas suatu aset (proyek riil) yang dapat digunakan dalam skala besar untuk membiayai pembangunan. Sukuk dipandang sebagai alternatif yang lebih baik daripada berutang karena antara lain mengandung unsur kerja sama investasi, berbagi risiko dan keterlibatan aset (proyek riil) yang juga mendasari penerbitan sukuk. ${ }^{2}$

Dalam konteks Indonesia, sejak tahun 2009, bulan Februari merupakan bulan yang sangat dinanti oleh para investor yang berminat untuk investasi di sukuk, termasuk Februari 2011 yang akan datang. Penerbitan Sukuk Ritel (SR) 003 tahun 2011 menurut berbagai sumber juga pada bulan Februari. Tentang jadwal pastinya masih menunggu informasi lebih lanjut, namun tidak akan jauh berbeda dengan tahun sebelumnya, dimulai pada minggu awal hingga ke-3 Februari, sedangkan penjatahan pada akhir minggu ke-3 Februari dan penerbitannya pada 2-3 hari sesudahnya.

Pada penerbitan perdananya di tahun 2009, agen penjual sukuk ritel (hanya) sebanyak 13 agen yang terdiri dari 4 bank konvensional, 1 bank syariah, dan 8

${ }^{1}$ Dosen Tetap dan Ketua Program Studi Ekonomi Islam, Fakultas Ilmu Agama Islam, Universitas Islam Indonesia.

${ }^{2}$ Rifki Ismal dan Khairunnisa Musari (2009b), Menggagas Sukuk sebagai Instrumen Fiskal dan Moneter. Bisnis Indonesia. 1 April. 
perusahaan sekuritas. SR 003 yang diterbitkan pada 2011 ini diperkirakan akan semakin bertambah jumlah agen penjualnya. Dari perspektif masyarakat, patut direspon positif itikad pemerintah yang mengincar investor ritel yang memiliki kemampuan pembelian Rp 5 juta. Bahkan pada penerbitan sebelumnya, pemerintah melakukan pembatasan terhadap investor kelas kakap yang membeli sukuk ritel. Untuk investor besar yang merupakan institusi telah disediakan oleh pemerintah sukuk bernama IFR (ijara fixed rate) yang minimal pembeliannya 1 Miliar.

Walaupun sukuk ini merupakan instrumen investasi yang sesuai syariah dan menjanjikan, akan tetapi masih banyak warga masyarakat yang masih tidak tahu, atau ragu-ragu dan masih khawatir terhadap eksistensi sukuk sebagai instrumen investasi, baik dari segi kehalalannya maupun keuntungannya. Oleh karena itu, dirasa masih sangat penting untuk dibahas dari berbagai aspeknya, terutama dari segi kehalalannya dan keuntungan serta risiko yang mungkin timbul, dan juga kiat berinvestasi di dalamnya.

\section{Sukuk: Sejarah, Pengertian, dan Tujuan Penerbitannya}

Dalam periode klasik, sukuk berasal dari bentuk jamak dalam bahasa Arab yakni 'sak' bermakna akta atau sertifikat kepemilikan. Sumber lain menyebutkan, kata tersebut kemudian menjadi asal dari kata 'cheque' dalam bahasa Eropa yang berarti sebuah dokumen yang merepresentasikan sebuah kontrak (contracts) atau pengalihan kepemilikan(conveyance of rights), obligasi(obligations) atau kewajiban yang harus dipenuhi (monies done) berdasarkan prinsip syar'’ah. Namun demikian, fakta historis menunjukkan bahwa sukuk merupakan produk yang digunakan secara luas pada abad pertengahan Islam untuk mentransfer kewajiban keuangan yang berasal dari perdagangan dan kegiatan komersial lainnya. ${ }^{3}$

Literatur lain menceritakan hal senada bahwa sukuk secara umum digunakan untuk perdagangan internasional di wilayah muslim pada abad pertengahan. Fakta historis menunjukkan bahwa sukuk secara nyata digunakan secara luas oleh masyarakat muslim pada abad pertengahan dalam bentuk surat berharga yang mewakili kewajiban pembiayaan yang berasal dari perdagangan dan kegiatan komersial. ${ }^{4}$

Dalam perkembangannya, upaya mengembangkan dan meluncurkan surat berharga mirip obligasi yang sesuai syariah dilakukan kembali pada 1978 oleh Yordania. Pemerintah setempat mengizinkan Bank Islam Jordan menerbitkan obligasi Islami yang dikenal dengan obligasi mukharadah. Hal ini kemudian diikuti dengan diterbitkannya Muqaradah Bond Act 1981. Upaya senada juga dilakukan Pakistan yang menerbitkan undang-undang (UU) khusus yang disebut Peraturan tentang Perusahaan Mudarabah

${ }^{3}$ Rifki Ismal dan Khairunnisa Musari (2009a), Sukuk Menjawab Resesi. Jurnal EkonomiaRepublika. 19 Maret.

${ }^{4}$ Nurul Huda dan Mustafa Edwin Nasution (2007), Investasi Pada Pasar Modal Syariah. Jakarta: Kencana, p. 122. 
dan Aturan Pengembangan dan Kontrol Mudarabah 1980. Sayangnya, tidak satupun dari semua upaya ini yang menghasilkan aktivitas berarti karena minimnya infrastruktur yang sesuai dan kurangnya transparansi dalam pasar tersebut. Penerbitan obligasi Islam yang pertama kali sukses adalah Government Investment Issues (GII) -sebelumnya dikenal dengan Government Investment Certificate(GIC) - yang dilakukan oleh pemerintah Malaysia pada 1983. Namun, langkah inovasi yang ada lamban dan institusi finansial Islam saat itu tidak dapat mengembangkan pasar aktif bagi sekuritas tersebut. Berikutnya, kesuksesan sekuritisasi aset dalam pasar konvensional menghadirkan kerangka yang justru dapat diaplikasikan untuk aset Islam. Pada akhir 1990, struktur berbasis aset yang cukup diakui dalam bentuk sukuk dikembangkan di Bahrain dan Malaysia. Struktur ini menarik perhatian investor dan peminjam karena dianggap kendaraan potensial untuk mengembangkan pasar kapital Islam. ${ }^{5}$

Pada dasarnya sukuk adalah suatu bentuk sekuritisasi aset. Berbeda dengan obligasi konvensional, di dalam transaksi sukuk harus dilandasi oleh aset yang berwujud (tangible asset). Pendapatan yang diperoleh dari sukuk ini pun berasal dari pemanfaatan dana yang tepat dan dijamin oleh aset yang riil. Di dalam sukuk, underlying aset dibutuhkan sebagai jaminan bahwa penerbitan sukuk didasarkan nilai yang sama dengan aset yang tersedia. Oleh karenanya, aset harus memiliki nilai ekonomis, baik berupa aset berwujud atau tidak berwujud, termasuk proyek yang akan atau sedang dibangun. Adapun fungsi underlying asset tersebut adalah: (i) untuk menghindari riba, (ii) sebagai prasyarat untuk dapat diperdagangkannya sukuk di pasar sekunder, dan (iii) akan menentukan jenis struktur sukuk. Dalam sukuk ijarah al muntabiya bittamliek atau ijarah-sale and lease back, penjualan aset tidak disertai penyerahan fisik aset tetapi yang dialihkan adalah hak manfaat (beneficial title) sedangkan kepemilikan aset (legal title) tetap pada obligor. Pada akhir periode sukuk, SPV wajib menjual kembali aset tersebut kepada obligor.

Mengacu pada Keputusan Ketua Badan Pengawas Pasar Modal dan Lembaga Keuangan Nomor 130/Bl/2006 tentang Penerbitan Efek Syariah, sukuk didefinisikan sebagai efek syariah berupa sertifikat atau bukti kepemilikan yang bernilai sama dan mewakili bagian penyertaan yang tidak terpisahkan atau tidak terbagi atas: (1) kepemilikan aset berwujud tertentu; (2) nilai manfaat dan jasa atas aset proyek tertentu atau aktivitas investasi tertentu; atau (3) kepemilikan atas aset proyek tertentu atau aktivitas investasi tertentu.

Menurut Accounting and Auditing Organisation for Islamic Financial Institution (AAOIFI, 2002), Sukuk adalah sertifikat yang menunjukkan nilai yang sama setelah penutupan subscription, penerimaaan dari nilai atas sertifikat dan meletakkanya untuk digunakan sebagaimana rencana, pemilikan saham dan hak atas asset yang nampak,

${ }^{5}$ Zamir Iqbal and Abbas Mirakhor (2008), Pengantar Keuangan Islam: Teori dan Praktik. Terjemahan. Edisi Pertama. Jakarta: Kencana, p. 224. 
pengunaan dan jasa, dan equity atas proyek yang disebutkan atau equity atas aktivitas investasi tertentu.

Menurut Undang-Undang Nomor 19 Tahun 2008 Tentang Surat Berharga Syariah Negara (SBSN), Sukuk Negara adalah surat berharga negara yang diterbitkan berdasarkan prinsip syariah, sebagai bukti atas bagian penyertaan terhadap Aset SBSN, baik dalam mata uang rupiah maupun valuta asing (pasal 1). Menurut fatwa DSN No. 69/DSN-MUI/VI/2008, Surat Berharga Syariah Negara atau dapat disebut Sukuk Negara adalah Surat Berharga Negara yang diterbitkan berdasarkan prinsip syariah, sebagai bukti atas bagian (ÍỐÉ) kepemilikan aset.

Sedangkan Sukuk Negara ritel adalah Surat Berharga Negara yang diterbitkan berdasarkan prinsip-prinsip syariah yang diperuntukkan bagi investor individu warga negara Indonesia. Sukuk Negara Ritel diterbitkan dalam bentuk tanpa warkat (scripless), namun kepada para investor akan diberikan Surat Bukti Kepemilikan.

Dalam UU No 19/2008 dikatakan bahwa underlying aset adalah aset SBSN, dimana aset SBSN adalah obyek pembiayaan SBSN dan/atau barang milik negara (BMN) yang memiliki nilai ekonomis, berupa tanah dan/atau bangunan maupun selain tanah dan/atau bangunan, yang dalam rangka penerbitan SBSN dijadikan sebagai dasar penerbitan SBSN. Adapun yang dimaksud barang milik negara adalah semua barang yang dibeli atau diperoleh atas beban anggaran pendapatan dan belanja negara (APBN) atau berasal dari perolehan lain yang sah.

Tujuan utama pemerintah menerbitkan sukuk negara adalah untuk membiayai $\mathrm{APBN}$, termasuk membiayai pembangunan proyek. Sebagaimana disebutkan pada pasal 4 UU SBSN bahwa tujuan SBSN diterbitkan adalah untuk membiayai Anggaran Pendapatan dan Belanja Negara termasuk membiayai pembangunan proyek. Proyek yang dapat dibiayai dengan sukuk negara adalah sektor energi, telekomunikasi, perhubungan, pertanian, industri manufaktur, dan, perumahan. Adapun manfaat dari penerbitan sukuk ini antara lain adalah: 6

1) Memperluas basis sumber pembiayaan anggaran negara;

2) Memperkaya instrumen pembiayaan fiskal.

3) Memperluas dan mendiversifikasi basis investor SBN.

4) Mendorong pertumbuhan dan pengembangan pasar keuangan syariah di dalam negeri;

5) Mengembangkan alternatif instrumen investasi.

6) Menciptakan benchmark di pasar keuangan syariah.

7) Mengoptimalkan pemanfaatan Barang Milik Negara dan mendorong tertib administrasi pengelolaan Barang Milik Negara.

${ }^{6}$ http://www.detikfinance.com/read/2009/07/01/094110/1156911/5/depkeu-tidak-adaaset-negara-yang-dijual-untuk-sukuk, diakses pada 12 November 2010 
Departemen Keuangan sebagai pihak yang merepresentasikan pemerintah menegaskan bahwa dalam setiap penerbitan sukuk atau surat berharga syariah negara, tidak ada aset negara yang dijual atau digadaikan.

Ketentuan penggunaan aset negara sebagai underlying asset penerbitan sukuk diatur dalam UU No. 19 Tahun 2008 tentang Surat Berharga Syariah Negara adalah sebagai berikut:

a. Hanya hak manfaat atas aset SBSN yang dijual/disewakan kepada SPV yang dibentuk Pemerintah berdasarkan UU No. 19 tahun 2008.

b. Tidak ada pemindahan hak kepemilikan (legal title) BMN (Barang Milik Negara).

c. Tidak ada pengalihan fisik BMN, sehingga tidak mengganggu penyelenggaraan tugas kepemerintahan.

d. Aset SBSN bukan sebagai jaminan (collateral).

Saat jatuh tempo Sukuk Negara atau terjadi default (gagal bayar), BMN tetap dikuasai pemerintah berdasarkan purchase $\mathcal{E}$ saleundertaking agreement. DPR memberikan persetujuan atas jumlah SBSN/Sukuk Negara yang diterbitkan dan atas jumlah aset SBSN yang dipergunakan dalam penerbitan Sukuk Negara dimaksud. ${ }^{?}$

\section{Legalitas Sukuk Perspektif Syariah dan Instrumen Akadnya}

Faktor utama yang melatarbelakangi hadirnya sukuk sebagai salah satu instrumen dalam sistem keuangan Islam adalah ketentuan al-Quran dan al-Sunnah yang melarang riba, maysir, gharar, bertransaksi dengan kegiatan atau produk haram, serta terbebas dari unsur tadlis. Terdapat sejumlah ayat ekonomi dalam Al-Qur'an yang berbicara tentang larangan riba. Turunnya ayat mengenai riba dalam Al-Qur'an secara bertahap, yaitu dalam empat tahap, ${ }^{8}$ yang terdiri dari 8 ayat dalam 4 surat (alBaqarah (2) = 5 ayat, Ali 'Imran (3) $=1$ ayat, al-Nisa' (4) = 1 ayat, al-Rum $=1$ ayat). Satu ayat diturunkan di Mekah dan selebihnya di Madinah. Gaya pengharaman riba dalam al-Quran adalah mirip dengan bentuk pengharaman khamr dalam al-Quran, ${ }^{9}$ yaitu tidak mengharamkan secara sekaligus tetapi berangsur-angsur. Bahkan dalam hadis pun juga terdapat kesamaan dalam hal dosa dari dua perbuatan dosa tersebut yaitu mendapat laknat dari Allah SWT. ${ }^{10}$

${ }^{7}$ http://indosukuk.com/2009/07/01/depkeu-tidak-ada-aset-negara-yang-dijual-untuksukuk/ diakses 12 November 2010

${ }^{8}$ Anwar Iqbal Qureshi (1961), Islam and The Theory of Interest, ed. 2, Lahore: SH Muhammad Ashraf, pp. 44-47; Ab. Mumin Ab. Ghani (1999), op.cit., p. 181.

${ }^{9}$ Wahbah al-Zuhaili (1997), al-Figh al-Islami wa Adillatuh, juz. 3, cet. 4. Beirut: Dar al-Fikr, p. 91.

${ }^{10}$ Hadis riba, lihat Ahmad bin Hanbal (1978), Musnad al-Imam Abmad bin Hanbal, juz 1, cet. 2. Beirut: Dar al-Kutub al-'Ilmiyyah, p. 83, sedangkan hadis khamr, lihat Ibn Majah (t.t.), Sunan Ibn Majah, juz. 2, Kairo: Matba'ah Dar Ihya' al-Kutub al-'Arabiyyah, p. 1122. 
Perlu dicatat, bahwa tidak semua sesuatu atau perkara yang diharamkan oleh Allah SWT tidak ada manfaatnya sama sekali atau hanya mendatangkan madarat saja. Ini terbukti dari ungkapan Allah dalam al-Quran surah Al-Baqarah (2): 219 tentang keharaman khamr, yang dinyatakan bahwa khamr itu juga mengandung manfaat tetapi madaratnya lebih besar dan berbahaya daripada manfaat yang mungkin diperoleh. Demikian juga riba, mungkin ia mengandung manfaat tertentu pada sekelompok orang tertentu, tetapi secara universal, madarat dan bahaya riba lebih besar daripada manfaat yang ditimbulkannya. ${ }^{11}$

Larangan riba juga ditemukan pada sejumlah Hadist. Jabir berkata bahwa Rasulullah SAW mengutuk orang yang menerima riba, orang yang membayarnya, orang yang mencatatnya, dan dua orang saksinya, kemudian beliau bersabda, "Mereka itu semuanya sama." (H.R. Muslim). Dari Abdullah bin Mas'ud r.a. dari Nabi Muhammad SAW. Beliau bersabda: "Riba itu ada 73 pintu, yang paling ringan diantaranya ialah seperti orang yang menikahi ibunya dan riba yang paling berat ialah merampas kehormatan seorang Muslim”. Diriwayatkan oleh Ibnu Majah dengan ringkas dan Hakim yang sempurna dan disahkan.

Hadist lain tentang larangan riba juga ditunjukkan dari Abu Hurairah r.a., ia berkata: Rasulullah SAW bersabda: "Emas dengan emas yang sama jenisnya dan timbangannya. Perak dengan perak yang sama jenisnya dan timbangannya. Barangsiapa yang menambah atau minta tambah, itu adalah riba”. Diriwayatkan oleh Muslim.

Sementara itu, larangan terhadap kegiatan yang mengandung maysir dapat ditemukan pada QS Al-Maidah: 90

$$
\text { تِلحون أيها الذين آمنوا إنما الخمر والميسر والأنصاب و الأزلام رجس من عمل الثنيطان فاجتنبوه لعلكم }
$$

Artinya: "Haiorang-orangyang beriman, sesunggubnya (meminum)khamar, berjudi, (berkorbanuntuk) berhala, mengundinasib dengan panah, adalab termasukperbuatan syaitan. Maka jaubilab perbuatan-perbuatan ituagarkamumendapatkeberuntungan.

Jika larangan maysir disebutkan dengan jelas dalam Al-Qur'an, larangan gharar tidak disebutkan dengan jelas dalam Al-Qur'an. Gharar adalah perilaku terlarang yang harus dhindari dalam setiap transaksi. Kata gharar dan derivasinya, diulang 27 kali dalam al-Quran, akan tetapi al-Quran menggunakan untuk term dalam teologi dan keagamaan (religious). Oleh karena itu, para fuqaha tidak merefer Alquran dalam kaitannya dengan larangan gharar dalam transaksi. ${ }^{12}$ Bahkan Vogel menandaskan bahwa

\footnotetext{
${ }^{11}$ Rafiq Yunus al-Misri (1999), Fa'idah al-Qard wa Nazariyyatuha al-Hadithah (Min Wijhati Nazri al-Islam), Beirut: Dar al-Fikr al-Mu'asir, pp. 34-35.

${ }^{12} \mathrm{Ahmad}$ Hidayat Buang (2000), Studies in The Islamic Law of Contracts: The Prohibition of Gharar. Kuala Lumpur: International Law Book Services, pp. 32-33.
} 
kata gharar dalam Alquran tidak pernah disebutkan dalam kaitannya dengan transaksi. ${ }^{13}$ Akan tetapi penyebutan larangan transaksi secara batil dalam Alquran (Q.S. al-Nisa' (4): 29), terkandung juga di dalamnya unsur gharar, karena para ulama memahami makna transaksi batil adalah transaksi di mana di dalamnya terdapat elemen-elemen riba, gambling (qimar), zulm, bakbs (ketidakadilan dalam praktek transaksi komersial), biyal (tipu daya), gharar, ketidakjelasan, dan objek akad yang ilegal. ${ }^{14}$

Sedangkan dalam hadis Rasulullah SAW terdapat banyak hadis yang menyatakan keharaman transaksi yang mengandung gharar. Kaharaman gharar dalam hadis ini merupakan suatu bentuk penjelasan khusus dari penjelasan Alquran tentang larangan bertransaksi secara batil. Hadis Rasulullah SAW menjelaskan secara lebih terinci keharaman transaksi yang mengandung unsur gharar, ${ }^{15}$ akan tetapi tidak sampai menyebutkan secara detail definisi dan skope serta ukuran gharar, sehingga para ulama fiqh dahulu pun juga tidak menjelaskan secara detail ukuran dan skope gharar. ${ }^{16}$ Adalah jelas bahwa terdapat banyak hadis Rasulullah SA W yang jelas melarangnya, ada yang langsung menyebutkan jenis transaksi tertentu dan terkadang tidak. Di antara hadishadis tersebut artinya adalah sebagai berikut: "Rasulullah SAW melarang jual beli gharar”. (H.R. Muslim), "Dilarang menjual ikan dalam laut, yang seperti itu gharar". (H.R. Ibn Hanbal), Dari Abdullah bin Umar r.a., katanya: "Rasulullah melarang jual beli habl al-habla seperti yang biasa dilakukan oleh orang-orang jahiliyyah". (H.R. Bukhari), Dari Abdullah bin Umar r.a., katanya Rasulullah SAW bersabda: "Janganlah kamu jual buah-buahan hingga nyata hasilnya, dan jangan kamu jual kurma basah dengan kurma kering”. (H.R. Bukhari).

Untuk transaksi yang mengandung unsur batbil (haram), sejumlah ayat seperti QS Al Baqarah: 188, QS Al Maa'idah: 38, QS Al Israa': 81, QS Al Muthaffifiin: 1-3, dan QS An Nisaa': 81 secara tegas melarang. Begitu pula dalam QS An Nisaa': 29. Sedangkan untuk larangan tadlis tercermin pada QS Al-An'am: 152.

Literatur lain menunjukkan bahwa legalitas sukuk bersumber utama dari QS Al-Baqarah: 282. Dewan fikih (fiqh academy) dari Organization of the Islamic Conference (OIC) dalam The 4th Annual Plenary Session February 1988 di Jeddah telah menyatakan bahwa syari'ah menuntut dokumentasi kontrak sebagaimana termuat dalam QS AlBaqarah: 282. Suatu transaksi yang tidak dilakukan secara tunai (cash) harus diwakili oleh sebuah dokumentasi sebagai bukti transaksi yang menggambarkan adanya hak dan kewajiban antara kedua belah pihak yang bertransaksi. Dewan fikih OIC

${ }^{13}$ Frank E. Vogel dan Samuel L. Hayes (1998), Islamic Law and Finance, London: Kluwer Law International, p. 64.

${ }^{14}$ Lihat misalnya Ibn 'Arabi (t.t.), Abkam al-Qur'an, juz. 1. Beirut: Dar al-Ma'rifa, h. 408; alJasas (t.t.), op.cit., juz. 2, p. 172.

${ }^{15}$ Ibn 'Arabi (t.t.), op.cit., juz. 1, p. 96.

${ }^{16}$ Sami al-Suwailem (2000), op.cit., p. 61; Frank E. Vogel dan Samuel L. Hayes (1998), op.cit., p. 64. 
memutuskan bahwa: (1) pengumpulan aset dapat direpresentasikan dalam sebuah catatan tertulis (written note) atau surat berharga (bond); (2) surat berharga atau catatan ini dapat dijual pada harga pasar (market price) sepanjang komposisi dari masing-masing kelompok aset, yang direpresentasikan dengan obligasi tersebut, meliputi mayoritas aset fisik dan hak finansial (financial right) dengan hanya minoritas yang menjadi uang tunai dan utang interpersonal. ${ }^{17}$

Lebih jauh, QS Al Baqarah: 282 sesungguhnya juga merupakan dasar pelaksanaan akuntansi Islam. Melalui ayat ini, Allah mengajarkan perlunya kegiatan tulis menulis di setiap transaksi, khususnya pada transaksi yang dilakukan tidak secara tunai. Hamka dalam Tafsir Al-Azhar Juz 3 tentang ayat ini menunjukkan, setiap transaksi dalam berniaga harus ditulis secara baik dan benar. Hal demikian dapat menjadi informasi penting dalam aktivitas niaga di masa mendatang. Dengan adanya pencatatan setiap transaksi, semua pihak akan lebih mudah memberi pertanggungjawaban. ${ }^{18}$

Intrumen akad dalam transaksi Sukuk Negara Ritel atau Surat Berharga Syariah Negara adalah Sale and Lease Back (al-Bay' ma'al Istijar). Instrumen ini berdasar fatwa DSN MUINo. 71/DSN-MUI/VI/2008. Transaksi ini diawali dengan penjualan (sale) hak manfaat atas Barang Milik Negara kepada investor yang melalui Perusahaan Penerbit SBSN (SPV). SPV menerbitkan Sukuk Negara Ritel kepada investor sebagai bukti kepemilikan hak manfaat atas barang yang diijarahkan (underlying asset) berupa BMN tadi. Kemudian investor melalui SPV menyewakan kembali (lease back) kepada pemerintah. Imbalan (kupon) yang diterima investor adalah dari bisnis lease atau sewa aset BMN kepada pemerintah. Dengan kata lain, sewa yang dibayarkan oleh pemerintah merupakan imbal hasil yang diterima oleh investor. Di akhir periode, Perusahaan Penerbit akan membeli kembali Sukuk Negara Ritel dan menjualnya kembali ke Pemerintah.

Mekanisme akad Sale and Lease Back (al-Bay' ma'al Isti'jar) adalah sebagai berikut:

${ }^{17}$ Salman Syed Ali (2005), Islamic Capital Market Products : Developments and Challanges, Jeddah: IRTI IDB, pp. 18-26.

${ }^{18}$ Lihat juga Sofyan Syafri Harahap. (2004). Akuntansi Islam. Jakarta: Bumi Aksara, pp. 119120. Hamka mengungkap secara jelas betapa wajibnya memelihara tulisan. Perintah ini kerap diabaikan umat Islam. Bahkan, yang lebih parah, penulisan transaksi kerap kali dipandang seolah-olah sebagai bentuk ketidakpercayaan. Padahal, hal ini merupakan perintah Allah. Dari ayat tersebut, kita dapat menyimak bahwa perintah melakukan pencatatan antara dua atau lebih pihak yang melakukan hubungan muamalah sudah ada sejak peradaban Islam. Dalam ayat tersebut, tersirat bahwa pencatatan dimaksudkan dengan tujuan pertanggungjawaban atau akuntabilitas, kebenaran, dan keadilan. Oleh karena itu, ketiga nilai tersebut sudah seharusnya inheren dalam sistem pencatatan. Prinsip akuntabilitas berkaitan dengan amanah yang harus ditunaikan. Prinsip keadilan berkaitan dengan etika yang harus dijunjung sesuai fitrah manusia. Prinsip kebenaran berkaitan sekaligus output dari prinsip keadilan dalam mengakui, mengukur, dan melaporkan transaksi-transaksi ekonomi. 
1. Akad yang digunakan adalah Bay'dan Ijarah yang dilaksanakan secara terpisah.

2. Dalam akad Bay', pembeli boleh berjanji kepada penjual untuk menjual kembali kepadanya aset yang dibelinya sesuai dengan kesepakatan.

3. Akad Ijarab baru dapat dilakukan setelah terjadi jual beli atas aset yang akan dijadikan sebagai obyek Ijarah.

4. Obyek Ijarah adalah barang yang memiliki manfaat dan nilai ekonomis.

5. Rukun dan syarat Ijarah dalam fatwa Sale and Lease Back ini harus memperhatikan substansi ketentuan terkait dalam fatwa DSN-MUINomor: 09/DSN-MUI/IV/2000 tentang Pembiayaan Ijarah.

6. Hak dan kewajiban setiap pihak harus dijelaskan dalam akad.

7. Biaya-biaya yang timbul dalam pemeliharaan Obyek Sale and Lease Back diatur dalam akad.

Penerbitan sukuk terlebih dahulu harus mendapatkan pernyataan kesesuaian prinsip syariah (syariah complianceendorsement) untuk meyakinkan investor bahwa sukuk telah distruktur sesuai syariah. Pernyataan syariah compliance tersebut dalam konteks Indonesia diperoleh dari Dewan Syariah Nasional - MUI. Untuk itu, DSN MUI telah mengeluarkan 4 fatwa terkait dengan penerbitan Sukuk Negara, yaitu:

1. Fatwa Dewan Syariah Nasional Nomor 69/DSN-MUI/VI/2008 tentang Surat Berharga Syariah Negara

2. Fatwa Dewan Syariah Nasional Nomor 70/DSN-MUI/VI/2008 tentang Metode Penerbitan Surat Berharga Syariah Negara

3. Fatwa Dewan Syariah Nasional Nomor 71/DSN-MUI/VI/2008 tentang Sale and Lease Back

4. Fatwa Dewan Syariah Nasional Nomor 72/DSN-MUI/VI/2008 tentang Surat Berharga Syariah Negara Ijarah Sale and Lease Back.

\section{Fitur Sukuk Ritel di Indonesia}

Sebagai gambaran terhadap fitur sukuk ritel yang diterbitkan pemerintah RI, ditampilkan secara umum fitur Sukuk Negara Ritel SeriSR 001 dan beberapa informasi tambahan sebagai berikut: ${ }^{19}$

\begin{tabular}{|l|l|}
\hline \multicolumn{1}{|c|}{ FITUR } & \multicolumn{1}{c|}{ KETERANGAN } \\
\hline Bentuk SR-001 & SBSN tanpa warkat (scripless) \\
\hline Akad & Ijarah-Sale \& Lease Back. \\
\hline Underlying Asset & $\begin{array}{l}\text { Barang Milik Negara (BMN) berupa tanah dan/atau } \\
\text { bangunan. }\end{array}$ \\
& $\begin{array}{l}\text { Menteri Keuangan menetapkan rincian BMN yang akan } \\
\text { digunakan sebagai Aset SBSN dalam rangka penerbitan } \\
\text { Sukuk Negara Ritel seri SR-001. }\end{array}$ \\
\hline
\end{tabular}

${ }^{19}$ Memorandum Informasi (prospektus) sukuk negara ritel seri SR-001, diterbitkan Pemerintah Republik Indonesia. 
Nur Kholis: Sukuk Instrumen Investasi yang Halal ...

\begin{tabular}{|c|c|}
\hline Issuer & Perusahaaan Penerbit SBSN Indonesia \\
\hline Investor & Perorangan (individu) \\
\hline $\begin{array}{l}\text { Nilai Nominal Per } \\
\text { Unit }\end{array}$ & Rp1 juta \\
\hline $\begin{array}{l}\text { Nilai Nominal } \\
\text { Pemesanan pembelian }\end{array}$ & $\begin{array}{l}\text { Rp } 5 \text { juta (5 unit) dan kelipatan Rp5 juta serta tidak ada } \\
\text { batas maksimum }\end{array}$ \\
\hline Tenor & 3 tahun \\
\hline Tradability & Tradable \\
\hline Kupon & $12 \%$ p.a dan dibayarkan setiap bulan pada tanggal 25 \\
\hline Tanggal Penerbitan & 25 Februari 2009. \\
\hline Tanggal Jatuh Tempo & 25 Februari 2012. \\
\hline Nominal Pelunasan & At par $(100 \%)$, bullet payment \\
\hline $\begin{array}{l}\text { Pasar Perdana: } \\
\text { - Biaya }\end{array}$ & $\begin{array}{l}\text { 1. Biaya Materai untuk Pernyataan dan Kuasa dan } \\
\text { Pembukaan Rekening Surat Berharga di Kustodian Bank } \\
\text { Bukopin } \\
\text { 2. Biaya penyimpanan Efek di Kustodian Bank Bukopin } \\
\text { sebesar 0.025\% p.a minimum Rp5.000/bulan. } \\
\text { Pajak Kupon sebesar 15\% (PPh Final) (PP No. } 16 \text { Tahun } \\
\text { 2009 tentang Pajak Penghasilan Atas Penghasilan Berupa } \\
\text { Bunga Obligasi) }\end{array}$ \\
\hline $\begin{array}{l}\text { Pasar Sekunder } \\
\text { - Biaya Transaksi } \\
\text { - Pajak }\end{array}$ & $\begin{array}{l}\text { Rp25.000 per transaksi. Apabila nasabah ingin membeli } \\
\text { sukuk di Pasar Sekunder maka biaya ditambah dengan } \\
\text { biaya-biaya yang dikenakan di Pasar Perdana. } \\
\text { Capital gain dan kupon berjalan (accrued return) sebesar } \\
15 \% \text { (PPh Non Final), dikenakan apabila nasabah } \\
\text { melakukan penjualan Sukuk Negara Ritel di Pasar } \\
\text { Sekunder. }\end{array}$ \\
\hline
\end{tabular}

\section{Plus Minus Investasi di Sukuk}

Islam sangat menganjurkan umatnya untuk melakukan aktifitas ekonomi (mu'amalab) dengan cara yang benar dan baik, serta melarang penimbunan barang, atau membiarkan harta (uang) tidak produktif, sehingga aktifitas ekonomi yang dilakukan dapat meningkatkan ekonomi umat. Dengan kata lain, investasi itu penting dilakukan oleh umat Islam. Beberapa tahun terakhir memang terlihat trend dari masyarakat muslim untuk lebih peduli pada peluang investasi, terlebih yang sesuai dengan Syariah.

Investasi adalah suatu kegiatan seseorang dalam mengfungsikan kekayaan untuk memperoleh pendapatan atau keuntungan lainnya dalam jangka panjang. Pengertian lain menyebutkan investasi bisa diartikan sebagai suatu tindakan untuk mengembangkan nilai aset yang kita punya. Investasi dapat dilakukan dalam sektor riil maupun keuangan. Investasi dalam sukuk negara ritel berarti adalah investasi di sektor keuangan. 
Sukuk Negara Ritel merupakan kesempatan emas bagi individu rakyat Indonesia untuk ikut berpartisipasi menyukseskan pembangunan negara. Untuk masyarakat muslim, ini merupakan instrumen investasi yang sangat aman dan sesuai syariah yang dikeluarkan negara khusus untuk individu rakyat Indonesia. Selain ikut berpartisipasi dalam pembangunan negara, investor juga akan mendapatkan imbalan yang sangat menarik yakni dengan kupon $12 \%$ untuk pembelian pada tahun 2009, semoga pada tahun 2011 tidak jauh berbeda.

Secara spesifik, keuntungan berinvestasi pada Sukuk Negara Ritel yang berkode SR adalah sebagai berikut:

1. Memberikan penghasilan berupa imbalan atau nisbah bagi hasil yang kompetitif, investor memperoleh imbalan yang lebih tinggi dari rata-rata tingkat bunga deposito bank BUMN.

2. Pembayaran imbalan dan Nilai Nominal sampai dengan sukuk jatuh tempo dijamin oleh Pemerintah. Imbalan bersifat tetap dan dibayarkan setiap bulan sampai dengan jatuh tempo.

3. Dapat diperjual-belikan di pasar sekunder sesuai dengan harga pasar, sehingga investor berpotensi mendapatkan capital gain di pasar sekunder.

4. Investasi yang aman, karena pembayaran imbalan dan nilai nominalnya dijamin oleh Undang-Undang.

5. Investasi yang menentramkan, karena tidak bertentangan dengan prinsipprinsip syariah seperti riba (usury), gharar (uncertainty), dan maysir (gambling).

6. Prosedur pembelian dan penjualan yang mudah dan transparan. ${ }^{20}$

Cara berinvestasi dalam sukuk negara ritel itu sangat mudah dan transparan. Bagi calon pembeli, caranya pemesanan pembelian sukuk negara ritel adalah sebagai berikut:

1. Menghubungi agen penjual yang melayani pemesanan pembelian Sukuk Negara Ritel.

2. Membuka rekening dana (jika diperlukan) pada salah satu bank umum dan rekening surat berharga (jika diperlukan) pada salah satu bank kustodian anggota subregistry atau partisipan/nasabah subregistry.

3. Menyetor dana sesuai jumlah pembelian ke rekening "Sukuk Negara Ritel" pada bank yang ditunjuk oleh agen penjual. Ini dilakukan dilakukan oleh agen penjual, investor tinggal menunjukkan dana yang akan digunakan untuk memesan Sukuk Negara Ritel.

4. Mengisi dan menandatangani formulir pemesanan serta melampirkan foto kopi KTP dan foto kopi bukti transfer dana.

5. Menerima tanda terima bukti pemesanan pembelian dari agen penjual.

${ }^{20}$ Ibid., pp. 5-6 
6. Menunggu hasil keputusan penjatahan yang ditetapkan pemerintah untuk mengetahui jumlah sukuk negara ritel yang dimenangkan.

7. Menerima konfirmasi kepemilikan sukuk negara ritel sesuai dengan jumlah pemesanan pembelian yang dimenangkan.

Di balik kelebihan sukuk ada sejumlah resiko yang perlu diperhatikan. Resiko sukuk dapat dibagi menjadi risiko pasar (market risk), risiko operasional (operational risk) dan risiko ketentuan syariah (shariah compliance risk). Market risk terdiri dari risiko suku bunga (interest rate risk atau rate of return risk) dan resiko nilai tukar (foreign exchange rate risk) dapat di jelaskan berikut.

1. Resiko tingkat bunga, sukuk ijarah, Istisna, salam dan yang didasarkan atas fixed rate menanggung akibat dari naik turunnya tingkat suku bunga. Kenaikan suku bunga menjadikan tingkat nilai sukuk kurang diminati oleh investor.

2. Resiko nilai tukar (foreign exchange rate) dapat dijelaskan bahwa sertifikat sukuk didenominasi di dalam Dolar Amerika (US\$) sehingga naik turunnya nilai rupiah terhadap dolar akan menjadikan nilai pembayaran terhadap investor akan berubah dari nilai awal. Seperti turunnya nilai rupiah terhadap dolar menjadikan beban pembayaran cicilan menjadi semakin besar kepada investor.

3. Resiko operasional sukuk (operastional risk) terdiri dari resiko kegagalan pembayaran (defaultrisk), resiko pembayaran kupon (coupon payment risk), resiko pelunasan asset (asset redemption risk), resiko SPV (SPV specific risk), resiko investor (investor specific risks), resiko berhubungan dengan aset (risk related to the asset).

4. Keterbatasan barang milik negara yang dapat dijadikan underlying asset. Sukuk merupakan sertifikat pembiayaan yang didasarkan atas jaminan aset rill yang besarnya didasarkan atas aset yang marketable di pasar keuangan global. Semakin banyak aset yang sesuai dengan standar yang ditentukan semakin besar bagi negara untuk mendapatkan pembiayaan dari investor internasional. Ini menunjukkan bahwa besarnya dana yang diperoleh di dasarkan besar aset yang kita miliki sehingga perlu juga kita memperbaiki sarana dan prasarana yang mendukung bagi persediaan aset yang layak jual. ${ }^{21}$

Secara umum, penerbitan SR 003 tahun 2011 kemungkinan nantinya tak berbeda jauh dengan SR 001 dan SR 002 yang diterbitkan 1-2 tahun sebelumnya. Dari sisi akad, harga nominal per unit, minimum pembelian, tenor, dan target pasar semuanya tak berbeda. Pemerintah sejauh ini optimis penerbitan SR 003 pada tahun 2011 akan mendulang sukses. Hal ini mengingat penerbitan sukuk ritel sebelumnya memperoleh respon positif di pasar dan tren dana yang terhimpun terus meningkat. Pada penerbitan sukuk ritel perdana SR 001 tanggal 25 Februari 2009, dana yang terhimpun sebesar Rp 5,556 triliun. Pada penerbitan SR 002 tanggal 10 Februari 2010, dana yang terhimpun meningkat menjadi Rp 8,03 triliun. 
Untuk penerbitan SR 003, diprediksi akan terjadi peningkatan pula atau setidaknya akan berada dalam kisaran himpunan dana SR 001 dan SR 002. Dalam penerbitan SR 003 kali ini, pemerintah tidak menetapkan target indikatif. Pemerintah lebih memilih wait and see seberapa besar penjualan jumlah instrumen yang dilakukan agen penjual.

Namun demikian, meski optimisme akan pasar sukuk ritel yang cukup besar dan menunjukkan tren meningkat, pemerintah tidak boleh mengabaikan pentingnya inovasi. Meski sukuk ritel memiliki keunggulan dalam hal underlying asset, bebas resiko gagal bayar (default risk), dan dapat diperdagangkan(tradeable), tetap saja sukuk ritel membutuhkan inovasi untuk mengantisipasi kemungkinan munculnya shocks yang unpredictable akibat kejenuhan. Misalnya dalam hal instrumen akad, yang selama ini berbasis akad ijarah. Hal ini memang tidak lepas dari tujuan penerbitannya untuk membiayai APBN secara umum. Pemerintah seyogyanya berupaya untuk menggunakan akad lain untuk memperoleh manfaat yang lebih besar. Hal ini mengingat implikasi dari akad ijarah relatif minim kepada sektor riil. Apalagi, dana penjualan sukuk yang diterima pemerintah cenderung tidak digunakan untuk sektor produktif.

Hal lain, adalah meski sukuk merupakan instrumen pembiayaan berbasis syariah, namun faktanya keikutsertaan bank syariah dalam penerbitan sukuk sebagai agen masih sangat kecil. Sejak terbit perdana tahun 2009 hingga tahun 2010 yang lalu, hanya ada 1 bank syariah yang menjadi agen penjual. Kenapa bank konvensional malah lebih banyak terlibat sebagai penjual. Ke depan, bank Syariah perlu lebih banyak dilibatkan.

\section{Penutup}

Dari paparan tersebut di atas, jelaslah bahwa secara historis sukuk merupakan produk yang digunakan secara luas pada abad pertengahan Islam untuk mentransfer kewajiban keuangan yang berasal dari perdagangan dan kegiatan komersial lainnya. Dalam konteks aplikasi dalam keuangan Islam modern, sukuk merupakan efek syariah berupa sertifikat atau bukti kepemilikan yang bernilai sama dan mewakili bagian penyertaan yang tidak terpisahkan atau tidak terbagi atas: (1) kepemilikan aset berwujud tertentu; (2) nilai manfaat dan jasa atas aset proyek tertentu atau aktivitas investasi tertentu; atau (3) kepemilikan atas aset proyek tertentu atau aktivitas investasi tertentu. Ketika sukuk diterbitkan oleh negara disebut dengan sukuk negara. Sukuk negara yang diperuntukkan untuk perorangan disebut sukuk negara ritel yaitu surat berharga negara yang diterbitkan berdasarkan prinsip syariah, sebagai bukti atas bagian penyertaan terhadap Aset SBSN, baik dalam mata uang rupiah maupun valuta asing. Sukuk merupakan peluang investasi yang halal, sesuai Syariah dan sangat menjanjikan. Sukuk risiko sangat kecil karena mendapat jaminan dari pemerintah, dalam jumlah yang tidak terbatas. Berbeda dengan deposito yang dibatasi maksimal yang dijamin adalah 2 Milyar. Berdasarkan fakta yang demikian itu, sudah selayaknya umat Islam 
Nur Kholis: Sukuk Instrumen Investasi yang Halal ...

yang kelebihan dana memanfaatkannya sebagai media investasinya karena sukuk sesuai dengan Syariah. Wallabi'alambial-Shawab.

\section{Daftar Pustaka}

Ahmad bin Hanbal (1978), Musnad al-Imam Abmad bin Hanbal, juz 1, cet. 2. Beirut: Dar al-Kutub al-'Ilmiyyah.

Ali, Salman Syed (2005), Islamic Capital Market Products:Developments and Challanges, Jeddah:IRTIIDB.

Ayub, Muhammad (2005), "Securitization, Sukuk and Fund Management Potential to be Realized by Islamic Financial Institutions”, Paper dipresentasikan pada 6th International Conference on Islamic Economic and Finance, Jakarta. 2124 November.

Buang, Ahmad Hidayat (2000), Studies in The Islamic Law of Contracts: The Probibition of Gharar, Kuala Lumpur: International Law Book Services.

Departemen Keuangan. Mengenal Sukuk: Instrumen Keuangan Berbasis Syariah, Direktoral Jenderal Pengelolaan Utang, Direktorat Kebijakan Pembiayaan Syariah. http://www.dmo.or.id.

Harahap, Sofyan Syafri (2004). Akuntansi Islam. Jakarta: Bumi Aksara.

http://indosukuk.com/2009/07/01/depkeu-tidak-ada-aset-negara-yang-dijualuntuk-sukuk/ diakses pada 12 November 2010

http://www.detikfinance.com/read/2009/07/01/094110/1156911/5/depkeu-tidakada-aset-negara-yang-dijual-untuk-sukuk, diakses pada 12 November 2010

Huda, Nurul dan Nasution, Mustafa Edwin (2007), Investasi Pada Pasar Modal Syariah, Cetakan Pertama, Jakarta: Kencana.

Ibn 'Arabi (t.t.), Abkam al-Qur'an, Juz. 1, Beirut: Dar al-Ma'rifa.

Ibn Majah (t.t.), Sunan Ibn Majah, juz. 2, Kairo: Matba'ah Dar Ihya' al-Kutub al'Arabiyyah.

Iqbal, Zamir dan Mirakhor, Abbas (2008), Pengantar Keuangan Islam: Teori dan Praktik (terj.), Edisi Pertama, Jakarta: Kencana.

Ismal, Rifki dan Musari, Khairunnisa (2009a), “Sukuk Menjarwab Resesi”, Jurnal EkonomiaRepublika, 19 Maret 2009.

(2009b), "Menggagas Sukuk sebagai Instrumen Moneter", Bisnis Indonesia. 1 April 2009.

al-Jasas (t.t.), Abkam al-Qur'an, Juz. 2. Beirut: Dar al-Ma'rifa.

Karim, Adiwarman Azwar (2007), Ekonomi Makro Islami. Edisi Kedua, Jakarta: Rajagrafindo Perkasa. 
Memorandum Informasi (Prospektus) Sukuk Negara Ritel Seri SR-001, diterbitkan Pemerintah Republik Indonesia.

al-Misri, Rafiq Yunus (1999), Fa'idah al-Qard wa Nazariyyatuha al-Hadithah (Min Wijhati Nazri al-Islam), Beirut: Dar al-Fikr al-Mu'asir.

Sriyana, Jaka (2009), "Peranan Sukuk Negara Terbadap Peningkatan Fiscal Sustainability”, Paper dalam Simposium Nasional Ekonomi Islam IV, 8-9 Oktober 2009 di Hotel Syahid Yogyakarta, ISBN 978-979-3333-36-6.

Qureshi, Anwar Iqbal (1961), Islam and The Theory of Interest, Ed. 2, Lahore: SH Muhammad Ashraf.

Vogel, Frank E. dan Hayes, Samuel L. (1998), Islamic Law and Finance, London: Kluwer Law International,

al-Zuhaili, Wahbah (1997), al-Figh al-Islami wa Adillatuh, Juz. 3, Cet. 4. Beirut: Dar alFikr. 